\title{
THE ECONOMIC CONSEQUENCES OF A FUEL LEVY REFORM IN SOUTH AFrica
}

\author{
Ramos Mabugu \\ Financial and Fiscal Commission, Midrand \\ Margaret Chitiga \\ Department of Economics, University of Pretoria \\ Hammed Amusa \\ Financial and Fiscal Commission, Midrand
}

\begin{abstract}
This paper assesses the economic effects of a hypothetical fuel levy imposed by South African provinces. The welfare effects of increasing the fuel levy by 10 per cent are negative but very small. Similarly, the marginal excess burdens for efficiency and equity (poverty) are quite low, suggesting much smaller impacts of the intervention on both economic activity and equity. Furthermore, a fiscal policy reform that raises fuel levy by 10 per cent is progressive as it has stronger negative effects on higher income households than on lower income households. A potential source of instability for the macroeconomy and total government revenue is the negative effect on economic activity induced by the fuel levy increase. The remedies suggested are that policymakers should make tax room elsewhere in the intergovernmental fiscal system to accommodate the fuel levy increase.
\end{abstract}

Keywords: Fuel levy; Intergovernmental Fiscal Relations; Social Accounting Matrix

JEL C4; D5: D6; E6; H2

\section{1 \\ Introduction}

Revenues from own sources constitute a small percentage of total revenue in each of South Africa's nine provinces. While local governments raise much of their own revenues, provinces do not have the taxation or borrowing resources to do so themselves. Given the high degree of vertical fiscal imbalance (VFI) in the country, together with the fact that provinces have been assigned responsibility for providing basic services, the issue of provinces raising their own revenue becomes important ${ }^{1}$. The 1996 Constitution explicitly recognises provinces' rights to levy certain taxes and surcharges. According to Section 228(1) of the Constitution, a provincial legislature may impose taxes, levies and duties other than income tax, value-added tax, general sales tax, rates on property or customs duties. In addition, provinces may levy flat-rate surcharges on the tax bases of any tax (other than the tax bases of corporate income tax, value-added tax, rates on property or customs duties), levy or duty that is imposed by national legislation. While the Constitution does give provinces some leeway to augment own revenues, it fails to provide specific details of what the other tax bases are on which provinces could impose levies or surcharges.

Consistent with the tenets of the Constitution, there are at least two approaches which provinces can follow in seeking to augment own revenues. The first approach is the one proposed by the Financial and Fiscal Commission (FFC) in its 1997 submission whereby provinces levy a surcharge on the personal income tax base. A second approach to augmenting provincial own revenues is a provincial surcharge on the national fuel levy. The objective of this paper is to analyse 
the effect of a fuel levy increase on the economy and welfare of households in South Africa. This issue has been given high policy relevance within the country's intergovernmental fiscal circles since the Western Cape government's proposal to levy such a fuel tax surcharge was approved by the Minister of Finance in August 2006.

There are at least two previous studies that have addressed this same issue in South Africa $^{2}$. The first is the work carried out by the Bureau of Economic Research (BER) at Stellenbosch University on behalf of the provincial government of the Western Cape (Smit et al., 2003). Using a combination of approaches, including the BER Macroeconometric Model, cointegration analysis, Input Output analysis and Tax Incidence analysis, the study reported that an increase in fuel levy would, in general, have minimal impact on macroeconomic aggregates such as the consumer price index (CPI) and gross domestic product (GDP). The main explanation for this result is the low price elasticity of demand for fuel products as well as the small size of the proposed change to the fuel levy. The second study is by MacDonald et al. (2006) which employs a computable general equilibrium (CGE) model to explore the effects of a 3 per cent (equivalent to 10 cents per litre) fuel levy increase. The data used is benchmarked to the year 2000 and the results also suggest that a provincial fuel levy does not have a dramatic effect on the economy. However, the study finds that the intervention imposes costs on the economy due to increased intermediate input costs, reduced international trade, real exchange rate appreciation and general multiplier effects. The loss in GDP is, however, large when compared to the amount of revenue gained from the fuel levy.

This study follows in the same vein as those studies but with three innovations. First, the study updates previous work and utilises a more up-todate 2004 Social Accounting Matrix (SAM) in its analysis. Second, the updated SAM features a disaggregation of the government into three spheres (namely central, provincial and local government) that more appropriately reflects South Africa's multi-layered intergovernmental fiscal system. Third, a criterion that exploits the concept of marginal excess burdens common in the public finance literature is developed and used to evaluate the desirability of the proposed policy intervention from an efficiency and equity perspective ${ }^{3}$.

The rest of this paper is divided as follows: Section 2 describes briefly the South African petroleum market so as to contextualise this paper. Section 3 describes the data and methodology used while section 4 discusses the policy simulation and results. The last section draws out policy implications and concludes the paper by highlighting pertinent areas for future research.

\section{2}

\section{Market and price mechanism for liquid fuels in South Africa}

South Africa's liquid fuel industry has a welldeveloped refinery capacity, and relies on a mix of domestic and foreign oil sources to meet domestic demand. According to the South African Petroleum Industry Association (SAPIA), domestic production of liquid fuels in 2005 amounted to 23571 million litres (SAPIA, 2006). Of the country's total domestic consumption, about 40 per cent of the demand is met by synthetic fuels (synfuels) produced by the South African Synthetic Oil Limited (SASOL) ${ }^{4}$. The remaining 60 per cent is sourced from crude oil imported from a number of countries - mainly Saudi Arabia, Kuwait, Nigeria and Iran. In 2001, 74 per cent of crude imports by volume were from Saudi Arabia, 2 per cent from Iran and 7 per cent from Nigeria, with the remaining 12 per cent coming mainly from Kuwait, the United Kingdom and Iraq (SANEA, 2003).

The pump price of petrol and the maximum wholesale price of diesel and paraffin are set by the Central Energy Fund (CEF) acting on behalf of the Department of Minerals and Energy. The prices are linked to the world market through the Basic Fuels Price (BFP) System which was instituted in April 2003 to replace the old "in bond landed cost" $\left(\right.$ IBLC) ${ }^{5}$ that made use of refinery gate prices posted by international refiners. The BFP consists of three main components - international market price of petroleum products, the freight costs ${ }^{6}$ of the imported petroleum, and "other" costs which 
cover fees related to insurance, cargo dues, stock financing and coastal storage. The retail price of petrol is changed every first Wednesday of the month to take into account movements in international prices and the exchange rate. The BFP is an import pricing parity which ensures that local refineries compete with the best in the world. It calculates the cost of fuel that would have been incurred if fuel had been imported from the most effective refineries in the world.
The prices of petrol, diesel and paraffin comprise external and internal factors. The external factors impacting the dollar basic fuel price and the exchange rate are beyond the control of the industry and change constantly in line with the movements of the international oil and financial market conditions (Figure 1). They are mainly responsible for the monthly movements in domestic prices of petroleum products (Figure 2).

Figure 1

Change in oil prices and exchange rate

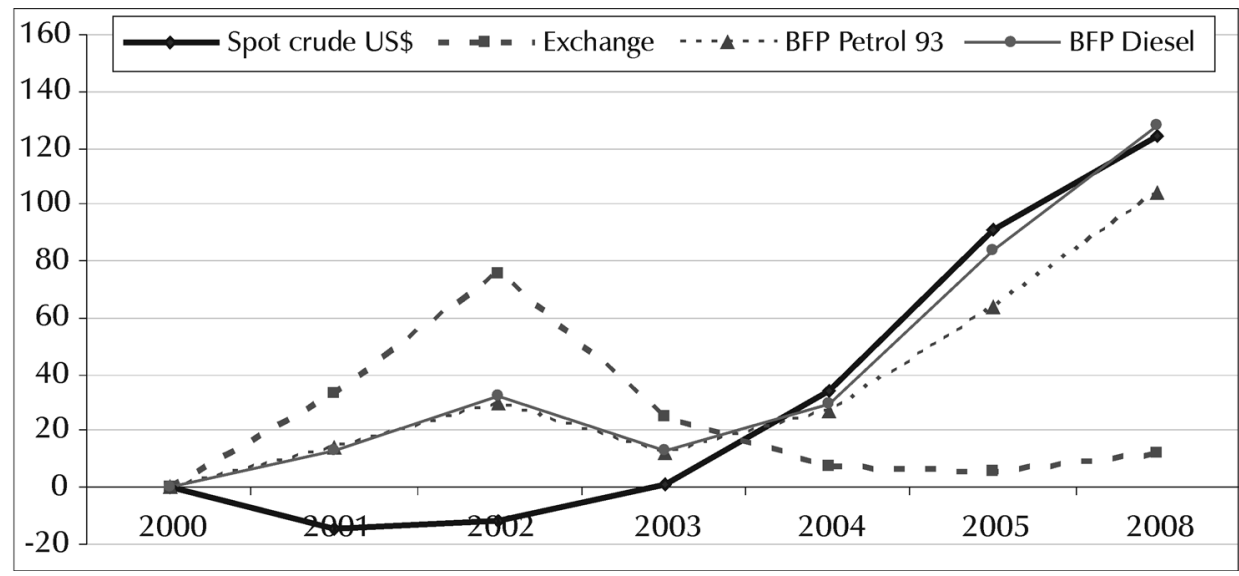

Source: http://www.dme.gov.za

Figure 2

Change in oil and oil products prices in South Africa

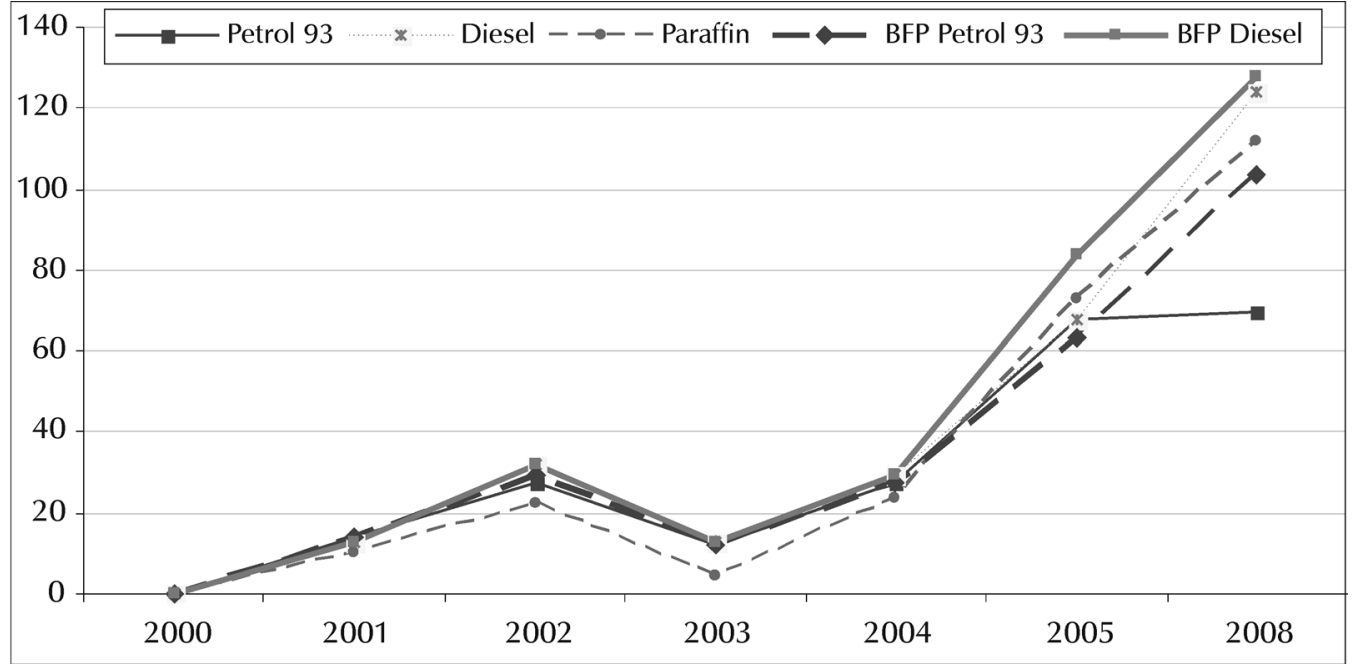


The internal factors include government taxes and levies, oil company margin, service differential, transport costs, and pump rounding factors. In general, these factors are adjusted on an annual basis and included monthly in the relevant price changes according to SAPIA. The pump price of petrol (Octane) in South Africa is mainly made up of the basic fuel price with levy (around 50 per cent) and tax of about 30 per cent. The remaining items comprise wholesale and retail margin, transport costs and delivery costs. Thus, the government already plays an important role in the determination of the price of fuel and can seek to be more involved in the face of increasing oil prices.

The IBLC/BFP accounts for the largest share of the pump price of unleaded fuel in South Africa. The fuel tax (consisting of a number of levies on fuel) has been the next biggest contributor to the fuel pump price since 2000 . The remaining government taxes consisting of the Road Accident Fund and Customs and Excise Taxes contribute a small share to the cost of fuel at the pump. The remaining components contribute a small share to the cost of fuel when taken individually but as a group have been contributing significantly to the cost of fuel. Most important amongst these are Wholesale and Retail Margins, which directly affect profitability of firms.

The share of IBLC/BFP in pump price of unleaded fuel has increased from 49 per cent before 2003 to 52 per cent after 2003. The BFP has thus effectively passed on more of the changes in the refined fuel prices to consumers than the IBLC previously did. This suggests that actual government response to high oil prices has since 2003 been to pass on increases to the market/consumer. The share of fuel tax in the pump price of unleaded fuel has been 23 per cent on average since 2000. However, this share has declined from 26 per cent before 2003 to 21 per cent in the post-2003 period. Thus, there has been some fuel tax reform/reduction.

The Road Accident Fund's share in the pump price has been around 5 per cent throughout the period 2000 to 2007. The share has increased between the period 2000-03 and 2004-07 from 4.6 per cent to 5.8 per cent respectively. Tariff policy plays a minor role in the fuel price formula. This is implied by the very small share of customs and excise taxes in the fuel pump price, which has been consistently hovering at a low 1 per cent of the pump price since 2000 , with no marked shift between the period before 2003 and that after 2003.

Transport costs, wholesale and retail margins (slate levy and delivery cost) together have contributed about 20 per cent to the pump price since 2000. There has been no discernible shift in this share when one compares the period prior to 2003 to that after 2003.

Currently, the general fuel levy is a nationally administered tax, collected by the South African Revenue Service (SARS), and forms part of the national revenue fund. Table 1 illustrates the current revenue accrued from the general fuel levy to national government from 2003 to 2007/08 and projected collections from 2008/09 to $2010 / 11$.

Table 1

Levies on fuel 2003 - 2011 (R millions)

\begin{tabular}{|l|c|c|c|c|c|c|c|c|}
\hline & $\mathbf{2 0 0 3 / 0 4}$ & $\mathbf{2 0 0 4 / 0 5}$ & $\mathbf{2 0 0 5} / \mathbf{0 6}$ & $\mathbf{2 0 0 6 / 0 7}$ & $\mathbf{2 0 0 7 / 0 8}$ & $\mathbf{2 0 0 8 / 0 9}$ & $\mathbf{2 0 0 9 / 1 0}$ & $\mathbf{2 0 1 0 / 1 1}$ \\
\hline Fuel Levy & 16,652 & 19,190 & 20,507 & 21,845 & 24,000 & 26,434 & 27,972 & 29,006 \\
\hline \% growth & & $15 \%$ & $7 \%$ & $7 \%$ & $10 \%$ & $10 \%$ & $6 \%$ & $4 \%$ \\
\hline
\end{tabular}

* Outer years are estimates 


\section{3}

\section{Model and data}

\section{(a) Modelling the effects of a fuel levy increase}

A change in fuel taxes affects fuel prices directly and that in turn impacts on production and consumption decisions. Firms use fuel in the production process directly and indirectly through using other goods that may have fuel inputs. Households will therefore purchase goods and services that will have direct and indirect fuel inputs. To model the transmission of price changes as a result of a fuel tax increase through the economy to the household sector, we use the SAM multiplier disaggregation approach. The model is underpinned by two basic assumptions, namely that the coefficients matrix is parametric and that total activity can passively accommodate a change in final demand ${ }^{7}$. Both of these assumptions are based on the long run assumption that all prices (and wages) ultimately remain the same. Because the SAM represents the idea that an economy is characterised by a circular flow of income and expenditure, a change in the demand for the product of one industry will not only affect that industry but all other activities will be affected indirectly through intermediate demand, factor demand, household demand, and government demand changes. Starting with the vector of final demands, successive rounds of gross outputs necessary to achieve that demand can be worked out. As further and further rounds are included, this converges onto an 'equilibrium'. Thus, the effects eventually die out. A multiplier is the cumulative sum of the endogenous effects. It is inversely related to the exogenous portion of economic activity.

In an $\mathrm{n}$ sector economy, let us denote sector i's output by $x_{i}$ demand for its produce by $f_{i}$ and the intermediate input from sector $i$ into sector $\mathrm{j}$ by $\mathrm{a}_{\mathrm{ij}} \mathrm{x}_{\mathrm{j}}$, where $\mathrm{a}_{\mathrm{ij}}$ are the input coefficients which are fixed in value ${ }^{8}$. The SAM uses the conceptual notion that the output of each sector can be used for final demand or as an intermediate input for other sectors, that is:

$x_{i}=\sum_{i} a_{i j} x_{j}+f_{i}$ or in matrix terminology:

$\mathrm{X}=\mathrm{AX}+\mathrm{F}$

Solving for $\mathrm{X}$, the relationship between $\mathrm{F}$ and activity vector $\mathrm{X}$ is easily shown to be:

$\mathrm{X}=(\mathrm{I}-\mathrm{A})^{-1} \mathrm{~F}$

where the term $(\mathrm{I}-\mathrm{A})$ is referred to as the technology matrix while $(\mathrm{I}-\mathrm{A})^{-1}$ is known as the multiplier matrix or Leontief Inverse. The Leontief Inverse gives the direct and indirect input requirements for the economy. The elements in a specific column account of the multiplier matrix show the effects on the row sectors and institutions of a one rand change in exogenous activity (extra-regional demand or relevant government expenditure) in the column account. Thus, the column coefficients show the backward linkages of a sector (purchases from sectors upstream). A specific account row shows how that account is affected by one-rand changes in the column accounts, or, the forward linkages of the sector (sales to sectors downstream). This is the wholemark of 'Linkage' analysis. Equation 3 can be expanded to produce the following:

$$
\begin{aligned}
X= & F+A F+A^{2} F+A^{3} F+A^{4} F \\
& +\ldots+A^{n} F
\end{aligned}
$$

In equation 4 we expand output per sector into its components of final demand to produce the number of units of each output used in the production of a unit of final demand for each $\operatorname{good}^{9}$. If tax, $t$, is applied and is passed on in its entirety to consumers, then the tax on goods consumed in final demand is $\mathrm{tF}$, the tax on the inputs to these goods is tAF, the tax on inputs to these is $t^{2} \mathrm{~F}$ and so on. Combining, total tax gives:

$$
\begin{aligned}
& \mathrm{tF}+\mathrm{tAF}+\mathrm{tA}^{2} \mathrm{~F}+\mathrm{tA}^{3} \mathrm{~F}+\ldots \\
& =\mathrm{t}(\mathrm{I}-\mathrm{A})^{-1} \mathrm{~F}
\end{aligned}
$$

\section{(b) Modelling the criteria for assessment of fuel taxes}

Before embarking on policy simulations, it is instructive to devise a criterion that can be used in evaluating the policy interventions. Abstracting for the time being from distributional issues, it is optimal to finance government's spending needs by equating the marginal excess burdens 
(MEB) across different revenue sources. A tax increase usually exacerbates the overall excess burden of the tax system. Distortionary taxes impose efficiency costs on the economy. The MEB of a tax can be defined as the first partial derivative of the gross domestic product to the tax revenue (of that specific tax), i.e.:

$$
\operatorname{MEB}(\text { Efficiency })=\frac{\partial G D P}{\partial \operatorname{TaxRevenue~}(\operatorname{tax})}
$$

Similarly, we can define the marginal poverty burden as the first partial derivative of poverty (inverse) to tax revenue. Marginal poverty burden in this case is described by the change in income of the poorest households (bottom 4 deciles), i.e.:

$$
\operatorname{MEB}\left(\text { Poverty) }(\operatorname{tax})=\frac{\partial \text { Poverty }}{\text { dTaxRevenue }(\operatorname{tax})}\right.
$$

These MEBs are used in this paper to assess whether the proposed fuel levy reforms are beneficial for output performance as well as poverty reduction. Their interpretations are discussed later together with the results.

\section{(c) The data}

The main database used is the 2004 SAM for South Africa. The SAM is itself based on the Stats SA SAM of 1998 and was updated by Conningarth for the FFC in order to reflect more recent data on National Accounts, sectoral GDP and output, households, governments, investment and trade. The SAM includes 46 economic activities ( 40 formal and 6 informal) and 48 household types. A novel feature of the SAM is the elaborate disaggregation of the government sector according to the hierarchy of tax/spending authorities (i.e. Central, Provincial and Local/Municipal), and in respect of the major revenue sources and major categories of expenditure. As in other countries, the Government of South Africa fulfils a cardinal role in the national economy. The collection of tax revenues and the spending thereof in the form of salaries, purchases of commodities, distribution of welfare grants and the building of public infrastructure all impact on the South African economy. The transfers between these government spheres and the interactions with the rest of the economy are incorporated in this SAM and this is a significant departure from previous South African SAMs that have a single government sector. Table A1 in the appendix reflects the results of this process.

Rather than focus on the generic details of the SAM, the rest of this section will describe the consumption of petroleum products by the industries and households, making use of the $\mathrm{SAM}^{10}$. The measures used cover both direct and indirect amounts of fuel consumption and so include both the fuels consumed directly by each sector and the fuels consumed in the production of the other inputs used in the sector. From the SAM we compute the share of expenditure on all fuels out of total production costs. Table 2 reports the total expenditure on fuel inputs as a percentage of total intermediate demand for industrial sectors. The sectors with the highest fuel consumption are the transport sectors, agriculture, petroleum, rubber products, chemicals and chemical products, construction and mining. Notice that although the direct expenditures for the other manufacturing sector are relatively small, the indirect industry expenditure is quite large. 


\section{Table 2}

Direct and indirect industry expenditure on petroleum products (as a per cent of Value of total production costs) at 2004 prices

\begin{tabular}{|c|c|c|}
\hline Sector & Direct & $\begin{array}{l}\text { Total (direct } \\
\text { and indirect) }\end{array}$ \\
\hline Agriculture & 7.7 & 12.4 \\
\hline Mining & 2.8 & 9.9 \\
\hline Meat, fish, fruit, vegetables, oils and fat products & 1.2 & 10.3 \\
\hline Dairy products & 0.8 & 9.6 \\
\hline Grain mill, bakery and animal feed products & 0.7 & 9.5 \\
\hline Other food products & 0.5 & 10.0 \\
\hline Beverages and tobacco products & 0.5 & 7.4 \\
\hline Textiles, clothing, leather products and footwear & 0.7 & 8.6 \\
\hline Wood and wood products & 0.4 & 9.2 \\
\hline Furniture & 0.5 & 8.7 \\
\hline Paper and paper products & 0.3 & 8.2 \\
\hline Publishing and printing & 0.3 & 8.7 \\
\hline Petroleum & 8.7 & 17.0 \\
\hline Chemicals \& chemical products (incl. plastic products) & 4.9 & 13.7 \\
\hline Rubber products & 5.3 & 14.1 \\
\hline Non-metallic mineral products & 1.0 & 9.4 \\
\hline Basic metal products & 2.7 & 11.7 \\
\hline Structural metal products & 0.3 & 9.4 \\
\hline Other fabricated metal products & 1.1 & 10.4 \\
\hline Machinery \& equipment & 1.7 & 9.8 \\
\hline Electrical machinery \& apparatus & 1.5 & 10.0 \\
\hline Communication, medical and other electronic equipment & 0.8 & 6.2 \\
\hline Manufacturing of transport equipment & 0.4 & 7.0 \\
\hline Handcrafts \& curios - informal & 0.4 & 10.7 \\
\hline Other manufacturing \& recycling & 0.7 & 8.1 \\
\hline Other manufacturing - informal & 0.1 & 8.7 \\
\hline Electricity & 0.5 & 8.6 \\
\hline Water & 0.9 & 8.9 \\
\hline Buildings & 1.5 & 10.1 \\
\hline Other construction & 3.5 & 11.7 \\
\hline Construction - informal & 0.3 & 10.8 \\
\hline Trade & 0.7 & 8.7 \\
\hline Accommodation & 0.9 & 8.2 \\
\hline Trade, accommodation \& entertainment - informal & 0.2 & 9.8 \\
\hline Transport services & 11.4 & 19.2 \\
\hline Transport - combi taxi & 2.8 & 11.2 \\
\hline Communications & 2.3 & 9.6 \\
\hline Insurance & 0.3 & 7.4 \\
\hline Real estate & 1.4 & 7.2 \\
\hline Business activities & 1.8 & 9.9 \\
\hline Health and social work & 1.8 & 9.3 \\
\hline Activities/services & 0.5 & 9.3 \\
\hline Other services - informal & 0.1 & 10.1 \\
\hline
\end{tabular}

Source: Authors' calculations based on Financial and Fiscal Commission Fiscal Social Accounting Matrix (2006) 
Policy changes that affect fuel prices will obviously affect households that consume fuels. Table 3 reports the distribution of direct and indirect petroleum expenditure by household consumption decile. Total expenditure on fuel is reported as a percentage of total expenditure for the decile. Focusing on direct expenditures, we see that petroleum expenditure is highly concentrated at the top of the distribution. While 2.1 per cent of expenditure is spent on petroleum products by the bottom decile, 3.9 per cent is spent by the top decile. Therefore, focusing exclusively on direct effects, the conclusion from this analysis would be that price changes induced by an increase in fuel levy will affect the rich more than the poor. On average though, the maximum fuel consumption is 3.1 per cent of total expenditure for all deciles, so that increases in fuel taxes will have a limited direct impact on household welfare.

Table 3

Direct household expenditure on fuels (as a per cent of value of total consumption) by decile (2004 prices)

\begin{tabular}{|l|c|c|}
\hline \multicolumn{1}{|c|}{ Decile } & Direct & Total \\
\hline 1 & 2.1 & 10.4 \\
2 & 2.8 & 11.5 \\
3 & 2.6 & 11.0 \\
4 & 2.4 & 10.7 \\
5 & 3.5 & 11.9 \\
6 & 2.6 & 11.0 \\
7 & 3.8 & 12.3 \\
8 & 3.6 & 12.2 \\
9 & 3.8 & 12.0 \\
10 & 3.9 & 11.1 \\
\hline AVERAGE & 3.1 & 11.4 \\
\hline
\end{tabular}

Source: Authors' calculations based on Financial and Fiscal Commission Fiscal Social Accounting Matrix (2006)

However, as argued before, fuel levy increases will not only affect the prices of fuels consumed by households but also the prices of other goods consumed because of the impact on the fuel inputs of these goods. The last column of Table 3 reports the total (direct and indirect) expenditure on petroleum products as a percentage of total expenditure for the decile. Due to higher dependence on the fuel intensive transport services and agriculture by the bottom deciles, the distribution of direct and indirect petroleum consumption is much flatter than before. While 2.1 per cent of the bottom decile's direct expenditure went on fuel, the percentage of direct and indirect consumption of fuel is much higher at 10.4 per cent because fuel is used in the production of goods and services such as public transport services and agriculture that the poor rely heavily on. Interestingly the conclusion is that the patterns of consumption are now more evenly spread than was the case when we only focused on direct expenditures. As well, when the effects of indirect inputs are included, on average, the maximum fuel consumption is 11.4 per cent of total expenditure compared to 3.1 per cent for all households, so that increases in the price of fuel will have noticeable impacts on the welfare of households.

\section{4}

\section{Simulation and results}

\section{(a) Scenarios for increasing the fuel levy in South Africa}

The Western Cape government was recently granted permission by the Minister of Finance 
to administer a fuel levy for the province. The proposal was circulated to provinces and discussed at the Budget Council in terms of the Provincial Tax Regulation Process Act in 2006. The Budget Council recommended that the province be given the go ahead to introduce a fuel levy. The Minister of Finance subsequently gave the Western Cape approval to introduce a fuel levy in July 2006. The fact that the Western Cape has been granted this permission means all other provinces can use the same tax handle, thereby giving provinces the capacity to raise more own source revenue which is important in promoting democratic and fiscally accountable government in the provinces. In brief, provinces are allowed to institute a fuel levy of 10-50 cents per litre of fuel - with some exceptions for marine bunker fuels used for shipping and fishing as well as aviation fuel (Smit et al., 2003). Using 95 Octane unleaded petrol as the base price, the fuel levy of 10-50 cents per litre will constitute 2.8-13.9 per cent of petrol price before any government levies. The fuel tax modelled in this paper is that of an increase of 10 per cent of fuel levy. There is no particular need to stick with this value, and the respective government is free to set the tax rate at the optimal level, bearing in mind that it cannot exceed the upper bound without the permission of the Minister of Finance. However, the selected value for simulation provides a convenient scenario for analysis and there is some value in establishing a precedent for future updates ${ }^{11}$.

\section{(b) Results}

This section considers the effect of a 10 per cent increase in the fuel levy instituted by all nine provinces in South Africa simultaneously. The impacts on the macroeconomy, sectoral production, households and welfare are considered separately. The entries in Table 4 show the impact on macroeconomic variables, measured by impacts on GDP, total revenue, fuel levy and imports. As would have been expected a priori, the policy simulation results in declines in GDP, imports and total government revenue. GDP drops by 0.31 per cent due to the reduction in aggregate demand induced by the tax increase. Fuel levy revenue increases by about 37 per cent from a base year level of R18,556.00 (an increase of about 7 billion rands). However, despite the increase in fuel levy revenue, government total revenue falls by 0.06 per cent. The main reason is that increases in fuel levy revenue are offset by reductions in other revenue heads which respond to shrinking economic activity (direct taxes and other indirect taxes) so that overall revenue falls. Similarly, imports decline by 0.11 per cent in line with the decline in economic activity. Thus, the measure leads to a reduction in economic activity.

Table 4

Percentage change in welfare in response to a 10 per cent change in fuel price

\begin{tabular}{|l|c|}
\hline & Per cent change \\
\hline Gross domestic product & -0.31 \\
Total revenue & -0.06 \\
Fuel levy & 37.73 \\
Imports & -0.11 \\
\hline
\end{tabular}

Source: Authors' calculations based on the model and Financial and Fiscal Commission Fiscal Social Accounting Matrix (2006)

A summary of the impact on sectoral output and supply of the exogenous 35 cent increase in the price of fuel is provided in Table 5. The sectors that are hurt the most are petroleum, chemicals and chemical products (including plastic) and transport services. These sectors have the largest direct expenditure dependence on petroleum products. Turning to the indirect impacts, we notice that although all sectors are negatively affected, agriculture, mining, electricity, trade and water are more negatively impacted than others. This is because of the higher linkages 
with the most affected sectors that these sectors have. However, the results suggest that the broad manufacturing sectors experience in general rather smaller negative impacts to both their production and supply compared to the economy-wide averages. This result is due in part to the higher level of disaggregation for the manufacturing industry than other industries and also because of the higher than normal import penetrations and intensities associated with the sectors in the base year period. The latter suggests that the sector experiences smaller leakages as imports are falling. The other services (other than transport services and trade) also experience minor reductions in their output as their initial fuel intensities were fairly modest.

\section{Table 5}

Percentage change in welfare in response to a 10 per cent change in fuel price

\begin{tabular}{|c|c|c|}
\hline & Base value (Million rands) & Change \\
\hline All activities & $2,448,750.00$ & $-0.10 \%$ \\
\hline All commodities & $2,970,827.00$ & $-0.10 \%$ \\
\hline Agriculture & $87,888.20$ & $-0.06 \%$ \\
\hline Mining & $171,598.91$ & $-0.14 \%$ \\
\hline Meat, fish, fruit, vegetables, oils and fat products & $47,572.74$ & $-0.07 \%$ \\
\hline Dairy products & $11,467.78$ & $-0.07 \%$ \\
\hline Grain mill, bakery and animal feed products & $21,037.39$ & $-0.06 \%$ \\
\hline Other food products & $59,247.80$ & $-0.07 \%$ \\
\hline Beverages and tobacco products & $55,019.89$ & $-0.07 \%$ \\
\hline Textiles, clothing, leather products and footwear & $71,474.77$ & $-0.06 \%$ \\
\hline Wood and wood products & $16,153.68$ & $-0.05 \%$ \\
\hline Furniture & $14,197.49$ & $-0.04 \%$ \\
\hline Paper and paper products & $48,115.67$ & $-0.08 \%$ \\
\hline Publishing and printing & $34,160.27$ & $-0.09 \%$ \\
\hline Petroleum & $103,064.27$ & $-1.43 \%$ \\
\hline Chemicals \& chemical products (incl. plastic products) & $136,941.58$ & $-0.18 \%$ \\
\hline Rubber products & $13,158.18$ & $-0.08 \%$ \\
\hline Non-metallic mineral products & $38,450.09$ & $-0.07 \%$ \\
\hline Basic metal products & $103,614.33$ & $-0.04 \%$ \\
\hline Structural metal products & $19,596.14$ & $-0.02 \%$ \\
\hline Other fabricated metal products & $36,016.74$ & $-0.09 \%$ \\
\hline Machinery \& equipment & $132,327.60$ & $-0.05 \%$ \\
\hline Electrical machinery \& apparatus & $35,811.26$ & $-0.04 \%$ \\
\hline Communication, medical and other electronic equipment & $48,538.78$ & $-0.03 \%$ \\
\hline Manufacturing of transport equipment & $192,844.70$ & $-0.06 \%$ \\
\hline Handcrafts \& curios - informal & 720.93 & $-0.03 \%$ \\
\hline Other manufacturing \& recycling & $29,557.88$ & $-0.06 \%$ \\
\hline Other manufacturing - informal & $2,313.05$ & $-0.02 \%$ \\
\hline Electricity & $46,587.45$ & $-0.10 \%$ \\
\hline Water & $14,397.24$ & $-0.10 \%$ \\
\hline Buildings & $78,404.50$ & $-0.03 \%$ \\
\hline Other construction & $52,686.96$ & $-0.03 \%$ \\
\hline Construction - informal & $2,887.14$ & $-0.06 \%$ \\
\hline
\end{tabular}




\begin{tabular}{|l|c|c|}
\hline & Base value (Million rands) & Change \\
\hline Trade & $99,846.58$ & $-0.10 \%$ \\
Accommodation & $51,510.51$ & $-0.08 \%$ \\
Trade, accommodation \& entertainment - informal & $22,878.55$ & $-0.03 \%$ \\
Transport services & $222,475.12$ & $-0.15 \%$ \\
Transport - combi taxi & $105,183.28$ & $-0.06 \%$ \\
Communications & $7,206.71$ & $-0.08 \%$ \\
FSIM & $52,047.57$ & $-0.07 \%$ \\
Insurance & $188,746.76$ & $-0.09 \%$ \\
Real estate & $161,748.79$ & $-0.07 \%$ \\
Business activities & $114,117.71$ & $-0.09 \%$ \\
Health and social work & $133,977.68$ & $-0.08 \%$ \\
Activities/services & $77,554.96$ & $-0.08 \%$ \\
Other services - informal & $7,679.38$ & $-0.07 \%$ \\
\hline
\end{tabular}

Source: Authors' calculations based on Financial and Fiscal Commission Fiscal Social Accounting Matrix (2006)

In terms of impact on household incomes, Figure 3 shows that all households are worse off as a result of the measure. Whites and Asians/ Indians experience the largest negative impact while Africans experience very small negative impacts from the measure. Disaggregating households into their respective deciles, the Figure shows that the measure is somewhat progressive. All other things being equal, we see that the effect on the top decile is over twice that for the bottom decile. The reason is that most of the petrol consumption in the bottom decile is indirect (used in the production of goods and services), while for the top of the distribution a relatively smaller proportion of consumption is indirect. As a result, a 10 per cent increase in the fuel levy will affect welfare through the impacts on other goods and services more for poor households than for rich households. The direct effect on fuel consumption will be more important in determining welfare changes for richer households.

Figure 3

Percentage change in welfare in response to a 10 per cent change in fuel levy

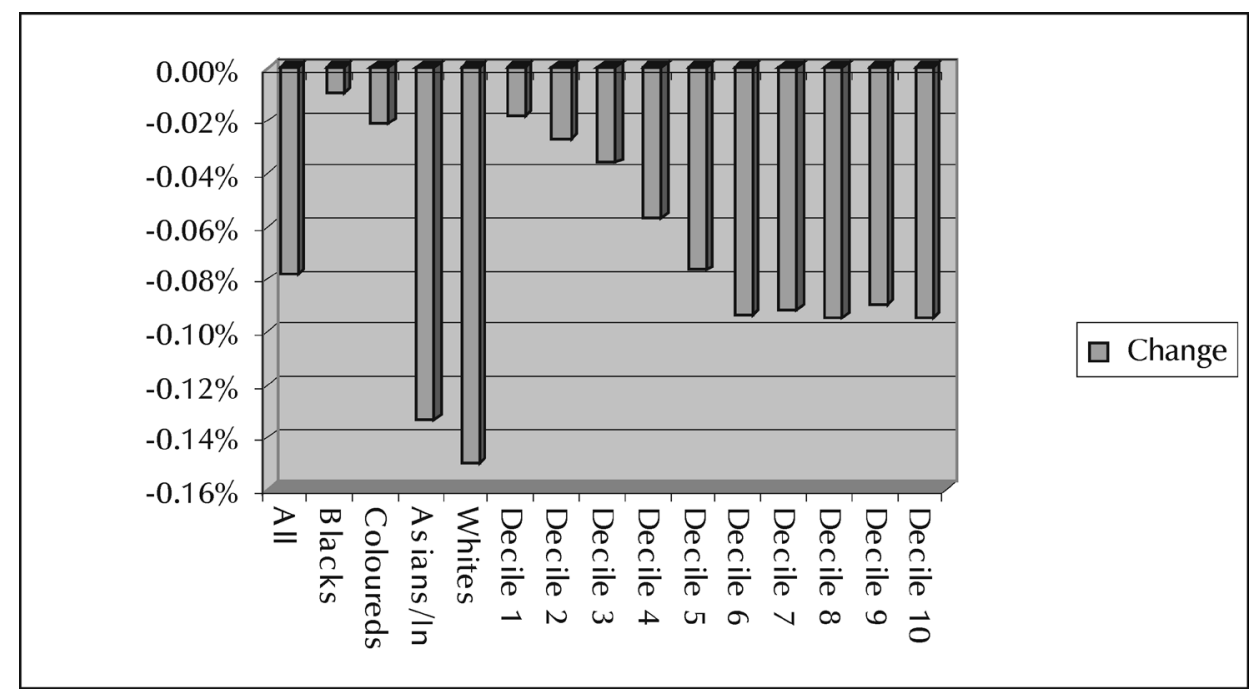

Source: Authors' calculations based on Financial and Fiscal Commission Fiscal Social Accounting Matrix (2006) 
Finally, using the MEB criteria developed in section 3 , the rest of this section reports the economy-wide incidences of the 10 per cent fuel levy increase by provinces as summarised by the
MEBs. The results are split into the different burdens, with MEBs for GDP and poverty for the tax handle. The results are reported in Table 6.

Table 6

Marginal excess burden of a 10 per cent fuel levy increase

\begin{tabular}{|l|c|}
\hline & Marginal excess burden \\
\hline Gdp/efficiency & 0.04 \\
\hline Poverty & 0.019 \\
\hline
\end{tabular}

Source: Authors' calculations based on Financial and Fiscal Commission Fiscal Social Accounting Matrix (2006)

The GDP MEB is largely in the range that would be expected a priori. To understand these results, one should first note that both GDP and government revenues are measured in million rands, which means the resulting MEB is without dimension since the rands cancel out. Hence, in the short run we would expect them to be small positive fractions. The general interpretation of these numbers is that higher MEBs are generally a sign that something is overtaxed (and vice versa). The numbers in Table 6 tell us that if provincial governments raise fuel levy as proposed, then for each incremental rand raised in provincial fuel levy revenues, GDP will decrease by approximately 0.04 rands. Thus, despite the large increase in fuel levy, the reform appears very efficient, reducing GDP by only 0.04 rands for each extra Rand raised in government revenue. However, to be conclusive about the efficiency of this tax, it is important to compare this tax to other taxes. The reason is likely to be that when fuel tax is increased, resources cannot move easily into less taxed sectors due to factor immobility and lower elasticities.

Next, let us look at the other criteria governments may use to evaluate the policy proposal, namely the poverty MEB. Recall that we have defined the marginal poverty burden as the change in consumption normalised by the change in tax revenue. The variable that we have used for (inverse) poverty is changes in income of poor households (bottom 4 households) multiplied by the corresponding initial price (this makes the variable's unit of measurement to be million rands, the same order as government consumption. Hence, marginal poverty burden is the change in private income of the four poorest household groups normalised by the change in fuel tax revenue. The income variable, like any other value in the SAM, is measured in rand values so that dividing it by tax revenues gives us a rand on rand measure. The results in Table 6 tell us that if the provincial governments raise fuel levy by 10 per cent per litre, then for every rand extra provincial fuel levy income, the poorest household consumption will decrease by close to 2 cents, quite a small number.

\section{5}

\section{Conclusions}

This paper uses a recently constructed fiscal social accounting matrix for South Africa to assess the likely effects of a hypothetical fiscal policy reform in which 10 per cent fuel levy increase is imposed by provincial governments. While fuel levy reform should ideally be located within the wider political context of fuel pricing, tax reform and regulation and intergovernmental fiscal relations, some results from the analysis carried out in this paper are instructive to this debate. Some of the reasons cited most commonly against fuel price increases are that such increases are a threat to domestic production, welfare and equity. The results of this paper do not find much support for these hypotheses.

The data and analysis suggest that the share of expenditure (both direct and indirect) on fuel is a small percentage of total expenditure for households and most of the industries. The welfare effects of increasing the fuel levy by 
10 per cent are therefore modest. Similarly, the marginal excess burdens for efficiency and equity (poverty) are quite low, suggesting much smaller impacts of the intervention on both economic activity and equity. Therefore, a provincial fuel levy increase of 10 per cent appears reasonable using these twin criteria of equity and efficiency. In fact, the results suggest that the fiscal policy reform proposal would be largely progressive.

A potential source of instability for the macroeconomy and total government revenue is the negative effect on economic activity induced by the fuel levy increase. The macroeconomic results suggest quite small negative impacts on the economy given the fairly large hypothetical increase in the fuel levy by provinces. The remedies to this potential instability would be to have respective government spheres make tax room elsewhere to accommodate this intervention. Thus as observed in van Heerden et al. (2006), it is important to present this tax instrument in a budget-balanced manner so that a fuel tax needs to be explicitly related to cuts in other taxes or government spending.

The shortcomings of this paper should be turned into areas for future research and a number suggest themselves. Potentially interesting extensions of the paper include extending the model in such a way that it can address (1) income effect feedback (2) building on the MEB figures to compare many tax handles, so that provincial governments can choose optimal taxes from a wider tax menu, and (3) including dynamic features into the model so that productivity and demographic shifts that affect the growth trajectory can be assessed.

\section{Endnotes}

1 The need to increase revenue as a means of enhancing the fiscal autonomy and accountability of sub-national governments is also consistent with the general fiscal decentralisation objective.

2 Wakeford (2006) and Kantor and Barr (1986) have addressed related issues focusing on oil price in general and not the fuel levy proposal.

3 In a related study, van Heerden et al. (2006) use a CGE model to find the potential for a double dividend if the revenue raised from an energy-related environmental tax is recycled to households and industry through lowering existing taxes. They find a triple dividend when any one of the environmental taxes is recycled through a reduction in food prices.

4 The synthetic fuels are produced using SASOL's uniquely developed programme of converting coal and natural gas to liquid fuels.

5 The BFP formula was negotiated and agreed upon by the African Minerals and Energy Forum (AMREF) and the SAPIA. When necessary and in line with global trends in crude oil prices, the BFP formula is adjusted on the first Wednesday of every month and takes into account the average daily international price movements in oil markets and exchange rate fluctuations based on a "3-working day optimization" mechanism. The IBLC was first introduced in the 1950s to coincide with the establishment of South Africa's first refinery and in 1995 was revised to factor in the introduction of market spot prices as a component in determining retail prices. However, over time, the use of refinery gate prices proved to be an inconsistent method for tracking world oil trade resulting in a loss of credibility in the use of the IBLC as a viable proxy for international fuel prices.

6 These freight costs reflect the costs of shipping petroleum imports from Augusta in the

Mediterranean, Singapore, and Mina-al-Ahmadi in the Arab Gulf.

7 This relies on the assumption that factor supplies are perfectly elastic.

8 In other words, $\mathrm{a}_{\mathrm{ij}}$ is the quantity of commodity $i$ that is required as an input to produce a unit of output $\mathrm{j}$.

9 For instance, AF gives the inputs needed to produce $\mathrm{F}$ while $\mathrm{A}^{2} \mathrm{~F}$ gives the inputs required to produce AF, etc.

10 Details on the rest of the SAM can be obtained from the authors upon request.

11 We have carried out extended sensitivity analyses. The results are stable within a wide range of price scenarios. We experimented with changes between 10 cents and 50 cents per litre increases and the direction of the results remain unchanged. As a result, we chose to report the mid-range scenario of $10 \%$, corresponding to 35 cents increase per litre of fuel.

\section{References}

DEPARTMENT OF MINERALS AND ENERGY

(DME) 2005. Digest of South African energy statistics 2005, available at Department of Minerals and Energy website: www.dme.gov.za. 
DEPARTMENT OF MINERALS AND ENERGY (DME) 2009. Archive of fuel prices, available at Department of Minerals and Energy website: www. dme.gov.za.

FINANCIAL AND FISCAL COMMISSION 2006. Fiscal social accounting matrix for South Africa. Financial and Fiscal Commission, Midrand, South Africa.

KANTOR, B.S. \& BARR, G.D.I., 1986. The impact of a change in the price of petrol on the South African rate of inflation. Journal for Studies in Economics and Econometrics, 26: 35-57.

MCDONALD, S., REYNOLDS, S. \& VAN

SCHOOR, M., 2006. Economic impact of a provincial fuel levy: A CGE analysis, South African Journal of Economics, 74(3): 422-451.

SANEA, 2003. South African energy profile 2003.

Johannesburg, South Africa.
SMIT, B., VAN DER BERG, S., KRUGER, D., ADAMS, I., ELLIS, L., GUTUZA, T., LOOTZ, L., MBANGELELI, K., MURRAY, C., PIENAAR, W., RAMUHULU, L., SALLER, K., SCHOLTZ, A. \& SHERATON, M. 2003. The feasibility of a fuel tax levy in the Western Cape. Bureau for Economic Research, November 2003.

SOUTH AFRICAN PETROLEUM INDUSTRY ASSOSIATION. 2006. SAPIA Annual Report 2006. _http://www.sapia.co.za.

WAKEFORD, J. 2006. The impact of oil price shocks on the South African macroeconomy: History and prospects. Paper presented at the DPRU/TIPS conference 2006 Johannesburg.

VAN HEERDEN, J., GERLAGH, R., BLIGNAUT, J., HESS, S., MABUGU, R. \& MABUGU, M., 2006. Searching for triple dividends in South Africa: Fighting $\mathrm{CO}_{2}$ pollution and poverty while promoting growth, Energy Journal, 27(2): 113-142. 


\section{Appendix}

\section{Table A1}

Income and expenditure of central, provincial and local government spheres of South Africa (2004 Prices (R millions))

\begin{tabular}{|c|c|c|c|}
\hline Current income & Central & Provincial & Local \\
\hline \multicolumn{4}{|l|}{ Activities: } \\
\hline Other taxes on production & 5,584 & & \\
\hline \multicolumn{4}{|l|}{ Commodities } \\
\hline Taxes on products (VAT) & 93,789 & & \\
\hline \multicolumn{4}{|l|}{ Capital (GOS): } \\
\hline Income from property & $-16,067$ & $-4,274$ & \\
\hline \multicolumn{4}{|l|}{ Enterprises: } \\
\hline Company tax & 65,460 & & \\
\hline Secondary tax on companies & 6,850 & & \\
\hline Taxes on retirement funds & 4,340 & & \\
\hline Taxes on payroll and workforce & 4,126 & & \\
\hline \multicolumn{4}{|l|}{ Taxes on property } \\
\hline Specific excise duties & 12,642 & & \\
\hline Levies on fuel & 6,866 & & \\
\hline Taxes on international trade $\&$ transactions & 12,068 & & \\
\hline Casino tax & & 506 & \\
\hline Motor vehicle licences & & 924 & \\
\hline Horseracing & & 68 & \\
\hline Other taxes & 7,969 & 6 & \\
\hline Interest, dividends and rent on land & & 340 & \\
\hline Fines and penalties & & 36 & \\
\hline Regional levies & & & 5,747 \\
\hline Property rates & & & 10,413 \\
\hline Electricity & & & 3,398 \\
\hline Water and sanitation & & & 5,415 \\
\hline Refuse removal & & & 1,695 \\
\hline Other tariffs & & & 6,262 \\
\hline
\end{tabular}


SAJEMS NS 12 (2009) No 3

\begin{tabular}{|c|c|c|c|}
\hline \multicolumn{4}{|l|}{ Households: } \\
\hline Personal income tax & 103,364 & & \\
\hline \multicolumn{4}{|l|}{ Taxes on property } \\
\hline Levies on fuel & 11,690 & & \\
\hline Stamp duties and fees & 1,216 & & \\
\hline Motor vehicle licences & & 1,015 & \\
\hline Interest, dividends and rent on land & & 373 & \\
\hline Fines and penalties & & 40 & \\
\hline Property rates & & & 5,364 \\
\hline Electricity & & & 2,816 \\
\hline Water and sanitation & & & 3,416 \\
\hline Refuse removal & & & 874 \\
\hline Other tariffs & & & 3,148 \\
\hline \multicolumn{4}{|l|}{ Rest of the world: } \\
\hline Transfers from the rest of the world & 1,033 & & \\
\hline Transfers from households & 2,929 & & \\
\hline Transfers from enterprises & 6,924 & & \\
\hline \multicolumn{4}{|l|}{ Allocations by government: } \\
\hline \multicolumn{4}{|l|}{ Rest of the world to central } \\
\hline \multicolumn{4}{|l|}{ Central to Provincial } \\
\hline Equitable share & & 141,933 & \\
\hline Conditional grants & & 18,225 & \\
\hline Interdepartmental transfers & & 1,374 & \\
\hline Provincial to local & & & 2,220 \\
\hline \multicolumn{4}{|l|}{ Central to local } \\
\hline Equitable share & & & 6,515 \\
\hline Conditional grants & & & 5,708 \\
\hline Total current income & 330,783 & 160,566 & 62,991 \\
\hline \multicolumn{4}{|l|}{ Current expenditure } \\
\hline Subsidies on production & 3,016 & 1,565 & \\
\hline
\end{tabular}


SAJEMS NS 12 (2009) No 3

\begin{tabular}{|c|c|c|c|}
\hline Subsidies on products & 2,446 & & \\
\hline Commodities & 50,614 & 27,988 & 32,931 \\
\hline Labour & 58,812 & 80,909 & 22,108 \\
\hline Current transfers to enterprises (interest on public debt) & 52,252 & 19 & 1,964 \\
\hline Transfers to households (pensions/grants) & 24,644 & 37,504 & \\
\hline Transfers to rest of the world & 10,637 & & \\
\hline \multicolumn{4}{|l|}{ Allocations: Expenditure } \\
\hline \multicolumn{4}{|l|}{ Rest of the world to Central } \\
\hline \multicolumn{4}{|l|}{ Central to Provincial } \\
\hline Equitable share & 141,933 & & \\
\hline Conditional grant & 18,225 & & \\
\hline \multicolumn{4}{|l|}{ Central to Local } \\
\hline Equitable share & 6,515 & & \\
\hline Conditional grant & 5,708 & & \\
\hline Provincial to Local & & 2,220 & \\
\hline Interdepartmental transfers & & 1,374 & \\
\hline Total expenditure & 374802 & 151578 & 57003 \\
\hline Total savings (Total income - Total expenditure) & -44019 & 8988 & 5988 \\
\hline Total savings (Total income - Total expenditure) & & $-29,043$ & \\
\hline Total gross investment & & $-37,887$ & \\
\hline Total depreciation & & 26,944 & \\
\hline Capital flows & & -39986 & \\
\hline
\end{tabular}

Source: Financial and Fiscal Commission Fiscal Social Accounting Matrix (2006) 